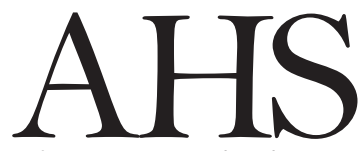

Advances in Horticultural Science

\title{
Kale seed priming with red seaweed biostimulant
}

\author{
F. Lemes Ternus ${ }^{1}$, V. Neumann Silva ${ }^{1}{ }^{(*)}$, P. Mendes Milanesi ${ }^{2}$, B. \\ Tortelli ${ }^{3}$ \\ 1 Universidade Federal da Fronteira Sul, Chapecó, Santa Catarina, Brazil. \\ 2 Universidade Federal da Fronteira Sul, Erechim, Rio Grande do Sul, \\ Brazil. \\ 3 Universidade de Passo Fundo, Passo Fundo, Rio Grande do Sul, Brazil.
}

OPEN ACCESS

(*) Corresponding author:
vanessa.neumann@uffs.edu.br

Citation:

LEMES TERNUS F., NEUMANN SILVA V., MENDES MILANESI P., TORTELLI B., 2021 - Kale seed priming with red seaweed biostimulant. - Adv. Hort. Sci., 35(2): 111-118

Copyright:

(c) 2021 Lemes Ternus F., Neumann Silva V., Mendes Milanesi P., Tortelli B. This is an open access, peer reviewed article published by Firenze University Press

(http://www.fupress.net/index.php/ahs/) and distributed under the terms of the Creative Commons Attribution License, which permits unrestricted use, distribution, and reproduction in any medium, provided the original author and source are credited.

Data Availability Statement:

All relevant data are within the paper and its Supporting Information files.

Competing Interests:

The authors declare no competing interests.

Received for publication 4 December 2020

Accepted for publication 17 March 2021
Abstract: Seed priming is a treatment that can contribute to improve seed physiological potential and increase its tolerance to abiotic stresses. Thus, this work evaluated the effect of kale seed priming with red seaweed biostimulant on physiological seed potential, seed health and tolerance to high temperature at germination. The experimental design was completely randomised, with a $2 \times 4$ factorial scheme. Treatments consisted of doses of $0,0.25,0.50$ and 1.0 $\mathrm{mL} \mathrm{L}^{-1}$ of red algae Solieria sp. biostimulant, and temperatures of 20 and $30^{\circ} \mathrm{C}$. The biostimulant used was subjected to chromatographic analysis to detect bioactive compounds. Seed imbibition curves were used to determine priming duration procedure. Treatments effects were evaluated by seed health, germination, root and shoot length, and dry mass, under ideal $\left(20^{\circ} \mathrm{C}\right)$ and stress $\left(30^{\circ} \mathrm{C}\right)$ temperatures. The results were submitted to analysis of variance, Tukey's test (temperatures) and regression (doses). The 22-h imbibition period is adequate for kale seed priming with Solieria sp. biostimulant. Kale seed priming with Solieria sp. does not interfere with seed health. The temperature of $30^{\circ} \mathrm{C}$ reduces kale seed germination index, as seedling root growth. The use of Solieria sp. biostimulant does not promote kale seed physiological potential.

\section{Introduction}

Kale (Brassica oleracea var. acephala) is a vegetable crop belonging to the Brassicaceae plant family, originating from the European continent, with excellent adaptation to mild temperatures. However, there is a demand for this vegetable throughout the year. Considering the tropical climate conditions on several countries, studies of the tolerance to high temperatures in kale production are necessary.

The use of seeds for kale seedlings production has been increasing in recent years, especially considering the increasing release of hybrid cultivars, which do not emit lateral shoots, preventing asexual propagation (Trani et al., 2015).

Seedlings production is one of the most important stages for horticul- 
tural production systems, which requires high-quality seeds. A key component of the performance of crop seeds is the complex trait of seed vigour. Crop yield and resource-use efficiency depend on successful plant establishment in the field, and it is the vigour of seeds that defines their ability to germinate and establish seedlings rapidly, uniformly and robustly across diverse environmental conditions (FinchSavage and Bassel, 2016).

One procedure that can be used to improve seed quality is physiological conditioning, also known as seed priming. Seed priming is a pre-sowing treatment that partially hydrates seeds without allowing radicle emergence. Consequently, primed seeds demonstrate rapid germination and improved germination rate and uniformity. Moreover, seed priming is often implicated in improving the stress-tolerance of germinating seeds (Chen and Arora, 2013). Some examples of success using this technique are verified in the literature, as exemplified in the use of seed priming in spinach seed treatment that resulted in high germination rates, seedling emergence, growth, maturity and yield; in this research the maximum seed vigour was obtained when seeds were treated with $6 \%$ concentration of Sargassum wightii (Brown Seaweed) (Takoliya et al., 2018).

Studying physiological and biochemical mechanisms involved in heat stress-tolerance in rice seeds, Hussain et al. (2016) found that the best performance and greater rice seedlings tolerance obtained from primed seeds, by different methods (hydropriming, osmopriming, redox priming, chemical priming, and hormonal priming) is associated with increased starch metabolism, high respiratory rate, lower peroxidation and increased capacity of the antioxidant defence system. In addition, other experimental results have shown that the higher germination efficiency and vigour (seedling growth) occur due to the mobilisation of reserves and the activation of genes responsible for the synthesis of vital enzymes during the priming procedure (Lal et al., 2018).

Seed priming can be performed with algae extracts or formulations (Sharma et al., 2014). Some researches demonstrated beneficial effects of seed priming with several seaweed species, for several horticultural crops, for example, tomato seeds primed with Anabaena minutissima, Ecklonia maxima and Jania adhaerens (Righini et al., 2021) and with Ulva lactuca and Padina gymnospora (SantacruzRuvalcaba et al., 2019); pepper seeds with Kappaphycus alvarezii (K-sap) and Gracilaria edulis
(Dutta et al., 2019).

Seaweeds are green, brown and red marine macroalgae. Extracts of brown seaweeds are widely used in horticulture crops, mainly for their plant growth-promoting effects and ameliorating effect on crop tolerance to abiotic stresses, such as salinity, extreme temperatures, nutrient deficiency and drought (Battacharyya et al., 2015). Red seaweeds (Rhodophyta) are sources of carrageenans, which are sulphated linear polysaccharides that represent major cellular constituents of this algae; Carrageenans improve plant growth by regulating various metabolic processes, such as cell division (Shukla et al., 2016).

Studying the effects of extracts and isolated molecules of two species of Gracilaria (Gracilariales, Rhodophyta) on early growth of lettuce, Torres et al. (2018) found a promoting effect of the aqueous extracts in lettuce root length. Nonetheless, there is a lack of studies testing red seaweeds for seed treatment, especially in seed priming protocols.

Therefore, the objective of this work was to evaluate the effect of kale seed priming with red algae biostimulant in seed performance under adequate conditions and thermal stress.

\section{Materials and Methods}

The experiment was carried out in a Seed and Phytopathology Laboratory, in two stages. In the initial stage, the imbibition curves were performed to determine the ideal time for priming. Kale seeds of the Brazilian cultivar Butter were used, and a Solieria sp. biostimulant, which has $7.5 \% \mathrm{Mn}$ and $13 \% \mathrm{~S}$; a density of $1.3 \mathrm{~g} \mathrm{~cm}^{-3}$, and is rich in carrageenans. The experimental design used was completely randomised, in a $2 \times 4$ factorial scheme (temperatures $\mathrm{x}$ doses), with four replications.

To determine the bioactive compounds present in the seaweed extract, a chromatographic analysis was performed, according to the methodology described below.

Methodology for the analysis of phenolic compounds by liquid chromatography high efficiency (HPLC)

The analyze were performed on HPLC equipment brand HP model 1100, Lichrospher RP18 column (5 $\mu \mathrm{m}$ ) equipped with $210 \mathrm{~nm}$ UV detector and quaternary pump system. The reverse phase analysis consisted of: solvent A - Milli-Q water with $1 \%$ phosphoric acid and solvent $B$ - Acetonitrile. The mobile phase 
pumping system was gradient, with $90 \%$ of solvent $A$ from 0 to $5 \mathrm{~min}, 60 \%$ of $A$ from 5 to $40 \mathrm{~min}$ and $90 \%$ of $A$ from 45 to $50 \mathrm{~min}$. The standard flow was maintained at $0.5 \mathrm{~mL} / \mathrm{min}$ according to Morelli (2010). The samples were filtered through Nylon membranes of $0.45 \mu \mathrm{m}$ pore diameter. The phenolic compounds were identified according to their order of elution and by comparing their retention time with those of their pure standards. Quantification was performed by the external standardization method, by correlating the area ( $\mathrm{mAU} * \mathrm{~s})$ of the compound peak to the standard curve performed with each standard evaluated (gallic acid, epigallocatechin, catechin, epicatechin, epigallocatechin gallate, rutin, ferulic acid, naringin, hesperidin, myricetin, resveratrol, quercetin, apigenin and canferol). The result is expressed in $\mu \mathrm{g} / \mathrm{mL}$ of extract.

\section{Seed imbibition curves}

Seed imbibition curves were constructed to define the priming period, performed using a method adapted from Ferreira et al. (2013). Briefly, four replicates of $\pm 0.1 \mathrm{~g}$ of seeds per treatment were soaked in solutions of $0,0.25,0.50$ and $1.00 \mathrm{~mL} \mathrm{~L}^{-1}$ Solieria sp. biostimulant in a plastic box $(11 \times 11 \times 3.5 \mathrm{~cm})$. Each box contained $50 \mathrm{~mL}$ of solution in the bottom, and a metallic screen on the top, with the seeds placed between four sheets of germitest paper previously wet (at five times its weight). The boxes were placed in a germination chamber (BOD) at $20^{\circ} \mathrm{C}$ until protrusion of the primary root.

To determine the amount of solution absorbed, seeds were removed from the germination chamber and the gerbox, dried with paper towels and weighed on a digital analytical balance, with an accuracy of $0.001 \mathrm{~g}$. After weighing, seeds were placed again in the gerbox and brought to the germination chamber. The evaluations were made within $60 \mathrm{~min}$, and when protrusion of the primary root occurred, the process was interrupted, registering the corresponding period. Afterwards, the results obtained in the imbibition curves were analysed, and the appropriate period for priming was determined, which must be previous to the protrusion of the primary root (Bewley et al., 2013).

\section{Seed priming}

In the second research stage, Solieria sp. biostimulant doses for seed priming were tested. The experimental design was completely randomised in a $2 \times 4$ factorial scheme (temperatures $x$ doses) with five replications. Seed priming occurs at $20^{\circ} \mathrm{C}$ for $22 \mathrm{~h}$ (defined in the previous stage), given the evaluated doses of $0,0.25,0.50$ and $1.00 \mathrm{~mL} \mathrm{~L}^{-1}$, according to the method described in the step of the seed imbibition curves. After priming, seeds were evaluated for health, germination (percentage and velocity index), root and shoot seedling length and dry seedling mass.

\section{Seed health}

Seed health was evaluated by the blotter test, with eight replicates of 25 seeds placed in plastic boxes $(11 \times 11 \times 3.5 \mathrm{~cm})$ containing three sheets of filter paper moistened with distilled water in a ratio of 2.5 times the dry paper weight. The seeds were incubated at $25^{\circ} \mathrm{C}$ for 7 days under a 12 -h photoperiod. After incubation, the seeds were examined individually under a stereomicroscope and optical microscope, counting the percentage of incidence, and the pathogens were identified based on their morphological characteristics (MAPA, 2009 b).

\section{Germination test}

The germination test was carried out at the ideal temperature for the species $\left(20^{\circ} \mathrm{C}\right)$ and the stress temperature $\left(30^{\circ} \mathrm{C}\right)$, separately. Four replicates of 50 seeds, already conditioned, were distributed on paper for germination ("germitest"), previously moistened with distilled water and kept in a germination chamber. The percentage of germination was evaluated on the fifth day (first count) and 10 days after sowing (DAS) (final count), according to the criteria established in the Rules for Seed Analysis (MAPA, 2009 a).

\section{Germination velocity index}

The germination velocity index was determined in conjunction with the germination test, with daily counts, counting seeds with protrusion of $2 \mathrm{~mm}$ of primary root according to the protocol proposed by Matthews and Powell (2011).

\section{Seedling length}

Seedling length was determined at the end of the germination test (10 DAS), with 20 normal seedlings per experimental unit, from which the shoot length and root length were determined with a ruler graduated in centimetres (Nakagawa, 1999).

\section{Seedlings dry mass}

The same seedlings used to evaluate the length were separated in shoots and roots and dried in a forced-air circulation oven at $65^{\circ} \mathrm{C}$ for $72 \mathrm{~h}$. Once dry, the samples were removed from the greenhouse and 
placed in a desiccator, and then weighed on a $0.001 \mathrm{~g}$ precision scale (Nakagawa, 1999).

\section{Statistical analysis}

The results were submitted to analysis of variance. Tukey's test $(p \leq 0.05)$ was used for the temperature factor, and polynomial regression was realised for the dose factor. All analyses were performed using Sisvar software (Ferreira, 2011).

\section{Results}

Chromatographic analysis of the algae extract revealed the presence of gallic acid, at a concentration of $63.9 \mu \mathrm{g} / \mathrm{L}$, as can be seen in Table 1 .

Kale seed imbibition curves with red seaweed (Solieria sp.) biostimulant showed an increase in the wet mass accumulation up to $14 \mathrm{~h}$, and the highest absorption peaks were obtained between 12 and 14 h. This period defines germination phase I (Fig. 1 a). Between 14 to $28 \mathrm{~h}$ of imbibition, the absorption was constant, without a significant increase in the control treatment, and this was denominated as phase II. After $28 \mathrm{~h}$, phase III germination started. Using the doses of $0.25,0.5$ and $1.0 \mathrm{~mL} \mathrm{~L}^{-1}$, the germination phase I occurred until 17, 13 and $17 \mathrm{~h}$, respectively, and in all cases, the root protrusion occurred with 28 $h$ of soaking (Fig. 1 b, c and d).

Table 1 - Identification (possible compound) and quantification of phenolic compounds

\begin{tabular}{lcc}
\hline Compound & $\begin{array}{c}\text { Quantification } \\
(\mu \mathrm{g} / \mathrm{L})\end{array}$ & $\begin{array}{c}\text { Retention time } \\
(\mathrm{min})\end{array}$ \\
\hline Gallic acid & 63.79 & 5.877 \\
\hline
\end{tabular}
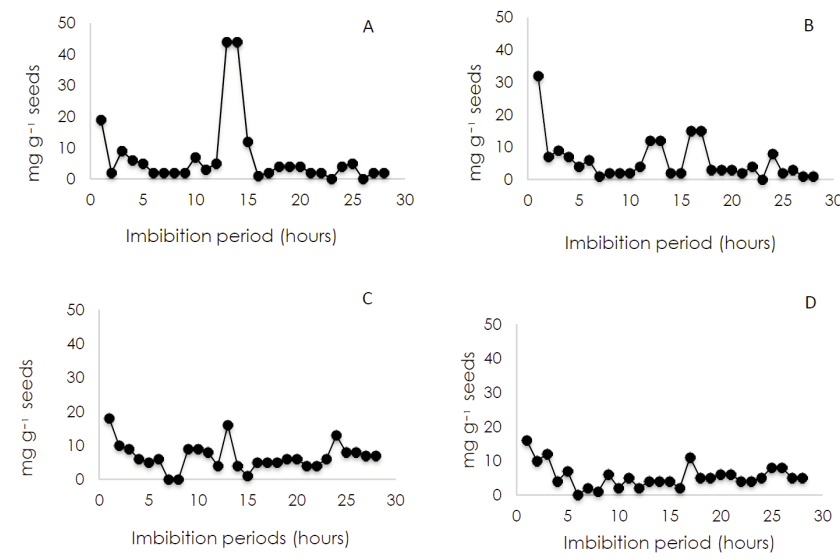

Fig. 1 - Inibibition curves of kale seeds primed with $0(A), 0,25$ (B), 0,50 (C) and 1 (D) $\mathrm{mL} \mathrm{L}^{-1}$ of Solieria sp. biostimulant.
For seed health, no difference was observed between treatments (Table 2). There was a low incidence of fungi, such as Penicillium spp., Rhizopus spp. and Cladosporium spp., and absence of Fusarium spp. However, although no statistical difference was observed, $0.37 \%$ of Trichoderma spp. was detected in the treatment with $0.25 \mathrm{~mL}$ of red algae.

Table 2 - Fungi incidence on kale seeds primed with doses red seaweed (Solieria sp.) biostimulant

\begin{tabular}{lcccc}
\hline \multirow{2}{*}{ Fungi } & \multicolumn{4}{c}{ Incidence $(\%)$} \\
\cline { 2 - 5 } & 0 & 0.25 & 0.5 & 1 \\
\hline Alternaria spp. & $4.1 \mathrm{NS}$ & 5.2 & 3.7 & 2.4 \\
Penicillium spp. & 0.37 & 0.12 & 3.37 & 0.37 \\
Rhizopus spp. & 0.12 & 0 & 0 & 0 \\
Cladosporium & 0.12 & 0.12 & 0 & 0 \\
Trichoderma spp. & 0 & 0.37 & 0 & 0.12 \\
\hline
\end{tabular}

NS = not significant by the Tukey test $(p<0.05)$.

Regarding the germination seed performance, differences between temperatures, without dose effects, were observed for the percentage and velocity index (Table 3).

There was a significant difference in seedling root length between the temperatures used, with a pro-

Table 3 - Means of germination count (G), radicle protrusion velocity index (RPVI), root length ( $R L$ ), dry root (DRM) and shoot (DSM) seedling mass from kale seeds primed with red seaweed (Solieria sp.) biostimulant, submitted to different germination temperatures

\begin{tabular}{lcccc}
\hline \multirow{2}{*}{ Temperature } & \multicolumn{5}{c}{ Doses $\left(\mathrm{mL} \mathrm{L}^{-1}\right)$} \\
\cline { 2 - 5 } G (\%) & 0 & 0.25 & 0.5 & 1 \\
20 & $82.5 \mathrm{a}^{*}$ & $85.5 \mathrm{a}$ & $88.0 \mathrm{a}$ & $86.0 \mathrm{a}$ \\
30 & $82.5 \mathrm{a}$ & $80.8 \mathrm{a}$ & $79.0 \mathrm{~b}$ & $70.8 \mathrm{~b}$ \\
$R P V I$ & & & & \\
20 & $82.8 \mathrm{a}$ & $85.9 \mathrm{a}$ & $87.5 \mathrm{a}$ & $86.0 \mathrm{a}$ \\
30 & $52.6 \mathrm{~b}$ & $48.0 \mathrm{~b}$ & $47.0 \mathrm{~b}$ & $48.9 \mathrm{~b}$ \\
$R L(\mathrm{~cm})$ & & & & \\
20 & $4.8 \mathrm{a}$ & $5.2 \mathrm{a}$ & $5.1 \mathrm{a}$ & $6.0 \mathrm{a}$ \\
30 & $2.7 \mathrm{~b}$ & $2.5 \mathrm{~b}$ & $2.5 \mathrm{~b}$ & $2.4 \mathrm{~b}$ \\
$D R M\left(\mathrm{mg} \mathrm{seedling}^{-1}\right)$ & & & & \\
20 & $4.8 \mathrm{a}$ & $2.9 \mathrm{a}$ & $5.0 \mathrm{a}$ & $4.8 \mathrm{a}$ \\
30 & $2.3 \mathrm{~b}$ & $4.0 \mathrm{a}$ & $3.8 \mathrm{a}$ & $3.1 \mathrm{a}$ \\
$D S M\left(\mathrm{mg} \mathrm{seedling}^{-1}\right)$ & & & & \\
20 & $3.2 \mathrm{~b}$ & $3.2 \mathrm{a}$ & $2.9 \mathrm{a}$ & $3.8 \mathrm{a}$ \\
30 & $4.6 \mathrm{a}$ & $3.5 \mathrm{a}$ & $3.5 \mathrm{a}$ & $4.8 \mathrm{a}$ \\
\hline
\end{tabular}

* Means followed by the same letter in the column, for each variable, do not differ from each other by Tukey test $(p<0.05)$. 
nounced reduction in root size when the seeds were exposed to $30^{\circ} \mathrm{C}$. However, the doses of biostimulant evaluated in this study did not differ and were not able to attenuate the effects of thermal stress (Table 3). In relation to shoot seedling growth, the opposite response was observed, with higher mean lengths at $30^{\circ} \mathrm{C}$ compared with $20^{\circ} \mathrm{C}$ (Fig. 2). In examining the effect of the biostimulant doses, at $30^{\circ} \mathrm{C}$, there was growth increment until the dose of $0.25 \mathrm{~mL} \mathrm{~L}^{-1}$, after which, the growth declined (Fig. 2b).

In regards to the accumulation of dry mass in roots and shoots of seedlings, no effects of biostimulant doses were observed (Table 3). For the temperature, a reduction in root length and increase in shoot length was verified in the control, which reinforces the hypothesis of the compensatory effect, related to plasticity.

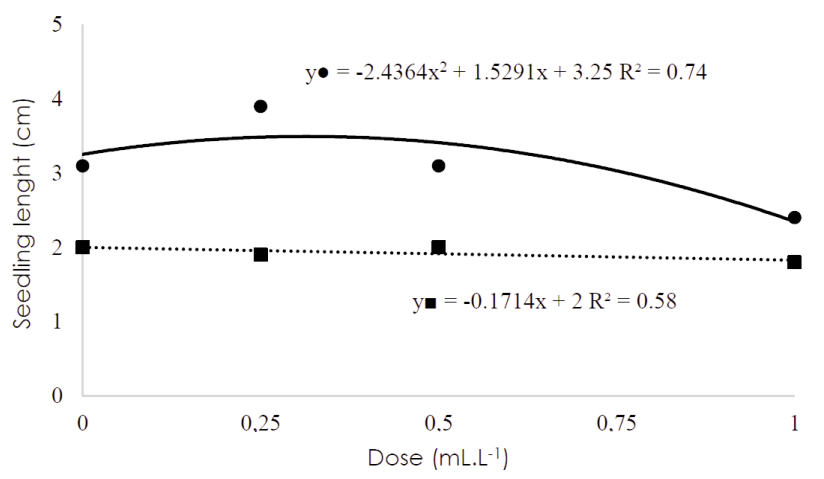

Fig. 2 - Averages of kale seedling shoot length, from primed seeds with red seaweed (Solieria sp.) biostimulant, submitted to $20^{\circ} \mathrm{C}(\boldsymbol{\square})$ and $30^{\circ} \mathrm{C}(\bullet)$ during germination.

\section{Discussion and Conclusions}

Regarding results of chromatographic analysis, which revealed the presence of gallic acid, it is important to consider that gallic acid is a secondary metabolite present in most plants and algaes (Cotas et al., 2020). Considered one of the major phenolic acids, gallic acid (or gallate) is a benzoic acid of great importance for the formation of a so-called galatotanin-hydrolyzable tannins group formed by a unit of sugar and a variable number of phenol acid molecule. This metabolite is known to exhibit a range of bioactivities including antioxidant and antimicrobial (Fernandes and Salgado, 2016).

Considering results of seed health, is important to mention that according to Machado et al. (2012), some Trichoderma strains are used to control phytopathogens and promote plant growth due to their versatility of action, such as parasitism, antibiosis and competition, as well as acting as inductors of plant resistance against diseases. Melo et al. (2017) observed progressive increases in phytoalexin concentration in soybean and sorghum seeds treated with increasing algae doses, demonstrating a high correlation between dose used and the amount of phytoalexin produced. Phytoalexins are compounds that have been studied a few years ago, which present mainly antimicrobial activity (Arruda et al., 2016).

The highest phytopathogenic fungi observed was Alternaria spp. (Table 2), however no differences between treatments were found. This fungus is a pathogen that can be transmitted by seeds and interferes with the germination and development of seedlings (Torres-Córtes et al., 2019).

Regarding the germination seed performance, differences between temperatures, without dose effects, were observed for the percentage and velocity index (Table 3 ). In general, germination capacity was reduced at $30^{\circ} \mathrm{C}$, indicating an abiotic stress effect in this process. Temperature exerts a marked effect on germination because it influences the performance of enzymes involved in the mobilisation of reserves, as well as enzymes associated with hormonal regulation.

In Arabidopsis, a model species in studies of physiology and genetics, and of the same botanical family of kale, it was verified that when seeds are exposed to high temperatures during germination, there is a stimulus to biosynthesis of abscisic acid (ABA) and, consequently, a repression of gibberellin synthesis (Toh et al., 2008). The balance between ABA and gibberellins is responsible for the occurrence of germination or maintenance of dormancy (Kucera et al., 2005). Furthermore, it should be noted that gibberellins stimulate the synthesis and production of hydrolases, especially alpha-amylase, resulting in seed germination (Miransari and Smith, 2014).

However, the inhibitory effects of ABA on seed germination include the impedance of radicle expansion and endosperm weakening, as well as increased expression of transcription factors, which may adversely affect the seed germination process (Graeber et al., 2010).

The absence of the effect of red algae on germination might indicate that this response is associated with the composition of the biostimulant and to the moment of application. One of the main compounds 
found in red algae is carrageenans, sulphated linear polysaccharides. Recent research has uncovered the biological activity of carrageenans and their oligomeric forms as plant growth promoters and elicitors of defence responses (Shukla et al., 2016).

However, carrageenans have shown a relatively greater effect when applied to plants at adult developmental stages. For example, according to Gonzales et al. (2013), oligo-carrageenans obtained by depolymerisation of red algae carrageenans increase the growth of tobacco plants by increasing photosynthesis and nitrogen assimilation, as well as stimulate the growth of 3-year-old Eucalyptus globulus plants.

Regarding results of seedling root length (Table 3) is worth mention that temperature stress has a detrimental effect on plant metabolism by interrupting cell homeostasis, and the direct result of cellular changes is increased accumulation of toxic compounds in cells, including reactive oxygen species (Essemine et al., 2010). According to Tsukagoshi (2016), reactive oxygen species regulate the activity of the root meristems and root development. Therefore, this mechanism is probably involved in the reduced growth of the kale seedling root accompanying the elevation of temperature, as verified in this work.

However, in relation to shoot seedling growth, the opposite response was observed (Fig. 2). This response might be explained by a mechanism of plasticity, in an attempt to balance the growth of the seedling, due to the reduction in root size. Hernandez-Herrera et al. (2014) found that there was a stimulatory effect of algae extracts on the length of plumule in tomato seedlings.

In regards to the accumulation of dry mass in roots and shoots of seedlings, no effects of biostimulant doses were observed (Table 3). As mentioned by Mašková and Herben (2018), the ratio of biomass partition between roots and shoots is essential for the ability of plants to compensate for the limited resources in the environment and thereby to survive and succeed in competition. Allocation plasticity is an important process for seedlings, and this is one of the most vulnerable phases of the breeding cycle, for most species. In this context, a rapid allocation response may have a direct impact on its survival (Lloret et al., 1999).

Regarding the biostimulant doses evaluated, it is possible that there were no effects on the accumulation of seedling dry mass because this process is more related to the issue of mobilisation and partition of the reserves, with little influence exerted by the compounds present in algae. However, considering that to date, there are no scientific studies to prove the direct effect of algae biostimulants in the process of mobilising seed reserves and partitioning of biomass in seedlings, additional studies in this area are necessary.

In conclusion, the 22-h imbibition period is adequate for kale seed priming with Solieria sp. biostimulant. Kale seed priming with Solieria sp. biostimulant does not interfere with seed sanity. The temperature of $30^{\circ} \mathrm{C}$ reduces velocity germination index and kale seedling growth, obtained from seeds primed with Solieria sp. biostimulant. The use of Solieria sp. biostimulant does not promote improvements in kale seed physiological potential under the conditions in which this research was carried out.

\section{References}

ARRUDA R.L., PAZ A.T.S., BARA M.T.F., CÔRTES M.V.C.B., FILIPPI M.C.C., CONCEIÇÃO E.C., 2016 - An approach on phytoalexins: function, characterization and biosynthesis in plants of the family Poaceae. - Ciência Rural, 46(7): 1206-1216.

BATTACHARYYA D., BABGOHARI M.Z., RATHOR P., PRITHIVIRAJ B., 2015 - Seaweed extracts as biostimulants in horticulture. - Sci. Hort., 196(30): 39-48.

BEWLEY J.D., BRADFORD K., HIRLHORST H., NONOGAKI H., 2013 - Seeds: Physiology of development, germination and dormancy. - Springer Verlag, New York, USA, pp. 392.

CHEN K., ARORA R., 2013 - Priming memory invokes seed stress-tolerance. - Environ. Exp. Bot., 94: 33-45.

COTAS J., LEANDRO A., MONTEIRO P., PACHECO D., FIGUEIRINHA A., GONÇALVES A.M.M., SILVA G.J., PEREIRA L., 2020 - Seaweed phenolics: From extraction to applications. - Mar. Drugs, 18(8): 1-47.

DUTTA S.K., LAEYK J., AKOIJAM R.S., BOOPATHI T., VANLALHMANGAIHA S.S., SINGH S.B., LUNGMUANA N.P., 2019 - Seaweed extract as natural priming agent for augmenting seed quality traits and yield in Capsicum frutescens L. - J. Appl. Phycol., 31: 3803-3813.

ESSEMINE J., AMMAR S., BOUZID S., 2010 - Impact of heat stress on germination and growth in higher plants: Physiological, biochemical and molecular repercussions and mechanisms of defense. - J. Biol. Sci., 10: 565-572.

FERNANDES F.H.A., SALGADO H.R.N., 2016 - Gallic acid: Review of the methods of determination and quantification. - Critical Rev. Anal. Chem., 46(3): 257-265.

FERREIRA D.F., 2011 - Sisvar: a computer statistical analysis system. - Ciência e Agrotecnologia, 35(6): 10391042.

FERREIRA R.L., FORTI V.A., SILVA V.N., MELO S.C., 2013 - 
Temperatura inicial de germinação no desempenho de plântulas e mudas de tomate. - Ciência Rural, 43(7): 1189-1195.

FINCH-SAVAGE W.E., BASSEL G.W., 2016 - Seed vigour and crop establishment: extending performance beyond adaptation. - J. Exp. Bot., 67(3): 567-591.

GONZALES A., CASTRO J., VERA J., MOENNE A., 2013 Seaweed oligosaccharides stimulate plant growth by enhancing carbon and nitrogen assimilation, basal metabolism, and cell division. - J. Plant Growth Reg., 32(2): 443-448.

GRAEBER K., LINKIES A., MULLER K., WUNCHOVA A., ROTT A., LEUBNER-METZGER G., 2010 - Cross-species approaches to seed dormancy and germination: conservation and biodiversity of ABA-regulated mechanisms and the Brassicaceae DOG1 genes. - Plant Mol. Biol., 73(1-2): 67-87.

HERNANDEZ-HERRERA R.M., SANTACRUZ-RUCALBA F., RUIZ-LOPEZ M.A., NORRIE J., HERNANDEZ-CARMONA G., 2014 - Effect of liquid seaweed extracts on growth of tomato seedlings (Solanum lycopersicum L.). - J. Appl. Phycol., 26: 619-628.

HUSSAIN S., KHAN F., HUSSAIN H.A., NIE L., 2016 Physiological and biochemical mechanisms of seed priming-induced chilling tolerance in rice cultivars. Front. Plant Sci., 7: 1-14.

KUCERA B., COHN M.A., LEUBNER-METZGER G., 2005 Plant hormone interactions during seed dormancy release and germination. - Seed Sci. Res., 15(4): 281307.

LAL S.K., KUMAR S., SHERI V., MEHTA S., VARAKUMAR P., RAM B., BORPHUKAN B., JAMES D., FARTYAL D., REDDY M.K., 2018 - Seed priming: An emerging technology to impart abiotic stress tolerance in crop plants, pp. 4150. - In: RAKSHIT A., and H. SINGH (eds.) Advances in seed priming. Springer Verlag, Singapore, pp. 511.

LLORET F., CASANOVAS C., PEÑUELAS J., 1999 - Seedling survival of Mediterranean shrubland species in relation to root: shoot ratio, seed size and water and nitrogen use. - Funct. Ecol., 13 (2): 210-216

MACHADO D.F.M., PARZIANELLO F.R., DA SILVA A.C.F., ANTONIOLLI Z.I., 2012 - Trichoderma no Brasil: o fungo e o bioagente. - Revista Cienc. Agrárias, 35(1): 274-288.

MAPA, 2009 a - Regras para análises de sementes. Ministério da Agricultura, Pecuária e Abastecimento, Secretaria de Defesa Agropecuária, Brasília, DF, Brazil, pp. 399.

MAPA, 2009 b -Manual de análise sanitária de sementes. Ministério da Agricultura, Pecuária e Abastecimento, Secretaria de Defesa Agropecuária, Brasília, DF, Brazil, pp. 399.

MAŠKOVÁ T., HERBEN T., 2018 - Root: shoot ratio in developing seedlings: How seedlings change their allocation in response to seed mass and ambient nutrient supply. Ecol. Evol., 8(14): 7143-7150.

MATTHEWS S., POWELL A., 2011 - Towards automated single counts of radicle emergence to predict seed and seedling vigour. - Seed Testing Inter., 142: 44-48.

MELO T.A., ARAÚJO M.U.P., SERRA M.R.S., PASCHOLATI S.F., 2017 - Produtos naturais disponíveis comercialmente induzem o acúmulo de fitoalexinas em cotilédones de soja e mesocótilos de sorgo. - Summa Phytopath., 43(3): 205-211.

MIRANSARI M., SMITH D.L., 2014 - Plant hormones and seed germination. - Envir. Exper. Bot., 99: 110-121.

MORELLI L.L.L., 2010 - Avaliação de compostos fenólicos majoritários em geleia de uva produzida com a variedade IAC-138-22 (máximo). - Dissertação de Mestrado, Universidade Estadual de Campinas, Brasil, pp. 133.

NAKAGAWA J., - 1999 - Testes de vigor baseados no crescimento de plântulas, pp. 49-85 - In: VIEIRA R.D., and N.M.CARVALHO (eds.) Testes de vigor em sementes. Jaboticabal, FUNEP, São Paulo, Brazil, pp. 164.

RIGHINI H., FRANCIOSO O., DI FOGGIA M., PRODI A., QUINTANA A.M., ROBERTI R., 2021 - Tomato seed biopriming with water extracts from Anabaena minutissima, Ecklonia maxima and Jania adhaerens as a new agroecological option against Rhizoctonia solani. - Sci. Hort., 281(30): 1-11.

SANTACRUZ-RUVALCABA F., HERNÁNDEZ-HERRERA R.M., HERNÁNDEZ-CARMONA G., 2019 - Germination and seedling growth responses of tomato (Solanum lycopersicum L.) to seaweed extracts applied on seeds. - Rev. Latin Biotec. Amb. y Alg., 10(1): 28-44.

SHARMA H.S.S., FLEMING C., SELBY C., RAO J.R., MARTIN T., 2014 - Plant biostimulants: a review on the processing of macroalgae and use of extracts for crop management to reduce abiotic and biotic stresses. - J. Appl. Phycol., 26 (1): 465-490.

SHUKLA P.S., BORZA T., CRITCHLEY A.T., PRITHIVIRAJ B., 2016 - Carrageenans from red seaweeds as promoters of growth and elicitors of defense response in plants. Front. Marine Sci., 3: 1-9.

TAKOLIYA H.H., PATEL R.V., BRAHMBHATT N., 2018 Improving green leafy vegetables seed germination using bio-priming treatment. - Inter. J. Recent Sci. Res., 9: 24774-24778.

TOH S., IMAMURA A., WATANABE A., NAKABAYASHI K., OKAMOTO M., JIKUMARU Y., HANADA A., ASO Y., ISHIYAMA K., TAMURA N., IUCHI S., KOBAYASHI M., YAMAGUCHI S., KAMIYA Y., NAMBARA E., KAWAKAMI N., 2008 - High temperature-induced abscisic acid biosynthesis and its role in the inhibition of gibberellin action in Arabidopsis seeds. - Plant Physiol., 146(3): 1368-1385.

TORRES P., NOVAES P., FERREIRA L.G., SANTOS J.P., MAZEPA E., DUARTE M.E.R., NOSEDA M.D., CHOW F., SANTOS D.Y.A.C., 2018 - Effects of extracts and isolated molecules of two species of Gracilaria (Gracilariales, Rhodophyta) on early growth of lettuce. - Algal Res., 32: 142-149.

TORRES-CORTÉS G., GARCIA B.J., COMPANT S., RESKI S., JONES P., PREVÉAUX A., BRIAND M., ROULET A., BOUCHEZ O., JACOBSEN D., BARRET M., 2019 - 
Adv. Hort. Sci., 2021 35(2): 111-118

Differences in resource use lead to coexistence of seedtransmitted microbial populations. - Sci. Reports, 9: 6648.

TRANI P.E., TIVELLI S.W., BLAT S.L., PANTANO A.P., TEIXEIRA E.P., ARAÚJO H.S., FELTRAN J.C., PASSOS F.A.,
FIGUEIREDO G.J.B., NOVO M.C.S.S., 2015 - Couve: do Plantio à colheita. - IAC, Campinas, SP, Brazil, pp. 42.

TSUKAGOSHI H., 2016 - Control of root growth and development by reactive oxygen species. - Current Opinion Plant Biol., 29: 57-63. 